\title{
Pengaruh Metode Mind Mapping Bersetting Team Game Tournament (TGT) Untuk Meningkatkan Prestasi Belajar Siswa
}

\author{
Muslim \\ Dosen STKIP Taman Siswa Bima \\ Email: muslimmathedu@gmail.com
}

\begin{abstract}
Penelitian ini bertujuan untuk mengetahui pengaruh pendekatan Mind Mapping bersetting team game tournament (TGT) untuk meningkatkan prestasi belajar siswa kelas VIII SMPN 1 palibelo. Jenis penelitian ini adalah penelitian eksperimen semu. Adapun populasi dalam penelitian ini adalah siswa kelas VIII SMPN 1 Palibelo yang terdiri dari dua kelas yaitu kelas VIII-B sebagai kelas eksperimen dengan pendekatan Mind Mapping bersetting team game tournament (TGT) dan kelas VIII-E sebagai kelas kontrol dengan metode pembelajaran konvensional.Instrumen penelitian yang digunakan adalah tes meningkatkan prestasi belajar berupa pret-test dan post-test berbentuk uraian. Berdasarkan hasil analisis data kelas eksperimen kelas eksperimen diperoleh nilai $t$-hitung adalah 9.544dan signifikannya adalah $0,749>0,05$ sehingga $\mathrm{H}_{0}$ ditolak atau pendekatan mind mapping bersetting(TGT) tidak berpengaruh untuk meningkatkan prestasi belajar siswa Sedangkan Pada kelas kontrol pembelajaran dengan metode ceramah dengan test-value 70 diperoleh t-hitung $=1,447$ dengan hasil signifikan $0,161>0,05$, maka $\mathrm{H}_{0}$ diterima. Hal ini dapat disimpulkan bahwa metode ceramah tidak berpengaruh untuk meningkatkan prestasi belajar siswa.
\end{abstract}

Kata Kunci: Mind Mapping, Team Game Tournament), Prestasi Belajar.

\section{PENDAHULUAN}

Teknologi yang semakin berkembang hampir menguasai dunia tidak terlepas dari hasil pemikiran manusia. Perkembangan teknologi saat ini seiring dengan perkembangan ilmu matematika, sebab matematika merupakan dasar dari semua ilmu pengetahuan yang lain. Penemuan-penemuan teknologi yang baru senantiasa beriring dengan perkembangan konsep dari ilmu matematika, sehingga dengan konsep matematika inilah teknologi dunia semakin berkembang. Konsep-konsep matematika yang dipelajari untuk hal ini tentulah membutuhkan kompetensi yang tinggi dan komprehensif.

Salah satu hal untuk meningkatkan kompetensi matematika menjadi lebih tinggi adalah melalui pendidikan, baik itu merupakan pendidikan formal ataupun non formal. Seperti yang kita ketahui pendidikan merupakan usaha sadar yang mempunyai tujuan untuk mempersiapkan siswa dalam belajar baik lewat suatu aktivitas mengajar, tuntutan serta latihan untuk peranannya di masa mendatang, sehingga siswa dapat mampu meningkatkan kemampuan dalam pelajaran.

Jurnal Ilmiah Mandala Education
Dalam pendidikan salah satu aspek yang sangat penting dalam proses pembelajaran adalah prestasi belajar. Prestasi belajar menjadi salah satu indikator utama dalam pelaksanaan pembelajaran yang baik. Apabila prestasi belajar siswa baik, maka dikatakan proses pembelajaran berhasil dan apabila prestasi siswa

belum mencapai hasil yang maksimal maka dikatakan proses pembelajaran belum berhasil.

Demikian halnya dalam pembelajaran matematika, prestasi belajar matematika merupakan hasil yang diperoleh siswa setelah melalui kegiatan belajar yang menggambarkan penguasaan siswa terhadap materi pelajaran matematika yang dapat dilihat dari nilai latihan, ulangan, raport, indeks prestasi studi angka dan predikat keberhasilan. Prestasi belajar yang dicapai siswa dapat dipengaruhi oleh dua faktor yaitu faktor internal dan eksternal (Slameto, 2003: 54). Penyebab utama kesulitan belajaradalah faktor internal yaitu diantaranya minat, bakat, motivasi, tingkat intelegensi, sedangkan penyebab utama problem belajaradalah faktor eksternal antara lain berupa strategi pembelajaran yang keliru, pengelolaan 
kegiatan belajar yang tidak membangkitkan motivasi belajar anak, maupun faktor lingkungan keluarga, masyarakat yang sangat berpengaruh pada prestasi belajar yang dicapai oleh siswa.

Pada kenyataannya prestasi belajar matematika siswa masih cenderung rendah. Hal ini dikarenakan siswa masih banyak yang menganggap matematika suatu pelajaran yang menakutkan, membosankan, tidak menarik dan di samping itu matematika bagi siswa bersifat abstrak, penuh dengan angka dan rumus-rumus. Agar tujuan pembelajaran dapat tercapai maka pembelajaran matematika haruslah berlangsung dengan melibatkan siswa, dalam artian pembelajaran berlangsung dengan efektif dan menyenangkan. Menurut Wuryani Djiwandono (2009: 227) Hakikat pembelajaran yang efektif adalah proses belajar mengajar yang bukan saja terfokus pada hasil yang dicapai oleh siswa namun bagaimana proses pembelajaran yang efektif mampu memberikan pemahaman yang baik, kecerdasan, ketekunan, kesempatan dan mutu serta dapat memberikan perubahan perilaku dan mengaplikasikannyadalam kehidupan mereka.

Dari hasil observasi di SMPN 1 Palibelo kelas VIII, menunjukkan bahwa prestasi belajar matematika siswa dalam pembelajaran matematika masih rendah ini dikarenakan guru masih menggunakan metode konvensional, kemauan belajar siswa kurang, terlihat dalam proses belajar mengajar matematika siswa tidak memperhatikan penjelasan guru, bahkan siswa tidak tertarik mengikuti pelajaran saat guru menjelaskan materi di depan kelas. Siswa juga enggan bertanya mengenai materi yang baru diterangkan, walaupun guru berulang kali meminta agar siswa bertanya jika ada hal-hal yang belum dipahami, sehingga nilai matematika siswa berada di bawah nilai pelajaran lain. Prestasi belajar matematika siswa juga belum menunjukkan hasil yang positif dan nilai siswa yang belum mencapai nilai $K K M \geq 70$. Ini terlihat dari hasil ulangan siswa pada materi aljabar semester ganjil kelas VIII dua tahun terakhir, dapat dilihat dalam tabel berikut:

Jurnal Ilmiah Mandala Education
Tabel 1.1 Nilai Rata-Rata Ulangan Semester Ganjil Mata Pelajaran Matematika di SMPN 1 Palibelo

jika ada hal-hal yang belum dipaham pelajaran lain. Prestasi belajar mateme nilai siswa yang belum mencapai nilai ] (Sumber : Daftar Nilai Ulangan Semester Ganjil Mata Pelajaran Matematika Kelas VIII SMPN 1 Palibelo tahun pelajaran 2015/2016)

Mengingat pentingnya prestasi belajar matematika maka, harus dicarikan solusi dari permasalahan yang terjadi. Salah satunya dengan metode mind maping. Mind Mapingmerupakan teknik meringkas bahan yang akan dipelajari dan memproyeksikan masalah yang dihadapi ke dalam bentuk peta atau teknik grafik sehingga lebih mudah memahaminya. Mind maping (peta pikiran) merupakan satu bentuk metode belajar yang efektif untuk memahami kerangka konsep suatu materi pelajaran. Kelebihan Mind Maping ini sendiri yaitu: Dapat mengemukakan pendapat secara bebas,dapat bekerja sama dengan teman lainnya dan catatan lebih terfokus pada inti materi. Sehingga diharapkan siswa dapat mengembangkan kemampuan belajar mandiri, siswa memiliki kemampuan untuk mengembangkan pengetahuannya sendiri dan guru cukup berperan sebagai fasilitator dalam proses pembelajaran.

Metode Mind Maping mempunyai kelemahan yaitu hanya siswa aktif yang terlibat, dari kelemahan Mind maping ini disettingkan dengan pembelajaran kooperatif tipeTGTyang merupakan pembelajaran yang dilakukan secara bersama-sama atau berkelompok, siswa dalam satu kelas dijadikan kelompok-kelompok kecil yang terdiri dari 4-5 orang untuk memahami konsep yang difasilitasi oleh guru, karena dalam pembelajaran kooperatif tipeteam games tournament(TGT)dalam pembagian kelompoknya yang memiliki kemampuan, jenis kelamin dan suku atau ras yang berbedadan dari pembelajaran kooperatif tipeTGT mempunyai kelebihanyaitu siswa menjadi lebih senang dalam mengikuti 
pelajaran karena ada kegiatan permainan berupa tournamen dan membuat siswa lebih bersemangat dalam mengikuti pelajaran, karena dalam pembelajaran ini guru menjanjikan sebuah penghargaan pada siswa atau kelompok terbaik. Sehingga memberikan kesempatan pada siswa untuk berkompetisi dengan sehat dan setiap anggota kelompok harus aktif, untuk meningkatkan prestasi belajar matematika siswa untuk menjadi kelompok terbaik.

Dari kondisi yang dipaparkan di atas agar pengajaran dapat mencapai hasil sesuai dengan tujuan yang direncanakan peneliti melakukan penelitian dengan judul "Pengaruh Pendekatan Mind Mapping BersettingTeam Game Tournament (TGT) Terhadap Prestasi Belajar Siswa Kelas VIII SMPN 1 Palibelo".

Dari uraian latar belakang masalah di atas, maka dapat diidentifikasi masalah dalam penelitian ini yaitu:

1. Proses belajar yang masih menggunakan metode konvensional

2. Prestasi belajar siswa pada materi aljabar di SMP Negeri 1 Palibelo masih belum optimal

3. Siswa kurang aktif dalam pelajaran matematika

4. Nilai matematika siswa masih dibawah nilai KKM yang ditentukan

Berdasakan latar belakang di atas, fokus penelitian yang dapat diambil adalah sebagai berikut:

1. Proses belajar hanya akan menggunakan metode Mind Mapping bersettingTeam Game Tournament (TGT).

2. Prestasi belajar siswa pada pelajaran Matematika akan ditingkatkan dengan penggunaan metode Mind Mapping bersettingTeam Game Tournament (TGT).

Berdasarkan identifikasi dan batasan masalah di atas, maka penulis merumuskan permasalahan yaitu apakah terdapatpengaruh pendekatan Mind Mapping bersettingTeam Game Tournament (TGT)terhadap prestasi belajar siswa kelas VIII SMPN 1 Palibelo tahun ajaran 2017/2018.

Berdasarkan rumusan masalah di atas, adapun yang menjadi tujuan penelitian ini yaitu untuk mendeskripsikan pengaruhpendekatan Mind Mapping bersettingTeam Game Tournament (TGT)terhadap prestasi belajar siswa kelas VIII SMPN 1 Palibelo tahun ajaran 2017/2018.

\section{KAJIAN PUSTAKA}

\section{Metode Mind Mapping}

a. Pengertian Metode Mind Mapping

Pada tahun 1975, Buzan telah mengembangkan suatu metode pembelajaran dalam dunia pendidikan yang dapat melatih siswa berpikir dengan lebih berdayaguna, yaitu suatu metode yang terkenal dengan istilah Mind Map (peta pikiran) dan sejak itu metode Mind Map (peta pikiran) berkembang dan telah banyak dipergunakan dalam pembelajaran.

Menurut Buzan (2009: 68) Mind Map (peta pikiran) adalah metode untuk menyimpan suatu informasi yang diterima oleh seseorang dan mengingat kembali informasi yang diterima tesebut. Mind Map (peta pikiran) juga merupakan teknik meringkas bahan yang dipelajari dan memproyeksikan masalah yang dihadapi ke dalam bentuk peta atau teknik grafik sehingga lebih mudah memahaminya. Mind map (peta pikiran) merupakan satu bentuk metode belajar yang efektif untuk memahami kerangka konsep suatu materi pelajaran.

Basuki (2010: 22) mengungkapkan bahwa Mind Map (peta pikiran) merupakan petunjuk bagi guru, untuk menunjukkan hubungan antara ide-ide yang penting dalam materi pelajaran. Menurut Hudojo (2011: 25) melalui proses pembelajaran dengan metode Mind Mapping ini, guru membimbing siswa mempelajari konsep suatu materi pelajaran. Siswa mencari inti-inti pokok yang penting dari materi yang dipelajari. Setelah siswa memahami konsep materi yang dipelajari, kemudian siswa melengkapi dan membuat peta pikiran. Kegiatan berikutnya guru memberikan contoh soal kemudian dikerjakan oleh siswa, kegiatan ini bertujuan untuk mengetahui seberapa jauh pemahaman konsep siswa terhadap suatu materi yang dipelajari. Sehingga diharapkan siswa dapat mengembangkan kemampuan belajar mandiri, siswa memiliki kemampuan untuk mengembangkan pengetahuannya sendiri dan 
guru cukup berperan sebagai fasilitator dalam proses pembelajaran.

Berdasarkan beberapa pendapat di atas, peneliti dapat menyimpulkan bahwa metode mind mappingmerupakan suatu cara memetakan sebuah infomasi yang digambarkan kedalam bentuk cabang-cabang pikiran dengan berbagai imajinasi kreatif. Selain itu mind mapping juga merupakan metode yang mempunyai banyak keunggulan, dimana dapat memudahkan cara belajar, penuh dengan ide-ide kreatif dalam menggambarkan mind mapping menjadi menyenangkan, siswa akan tertarik untuk belajar dan mengembangkan pengatahuannya dan membuat siswa lebih percaya diri.

Menurut Buzan (2008: 171) dalam bukunya yang berjudul "Buku Pintar Mind Map" menunjukan bahwa Mind Map (peta pikiran) ini akan membantu anak:

1) Mudah mengingat sesuatu,

2) Mengingat fakta, Angka, dan Rumus dengan mudah,

3) Meningkatkan Motivasi dan Konsentrasi,

4) Mengingat dan menghafal menjadi lebih cepat.

Buzan juga menunjukan bahwa siswa akan menghafal dengan cepat dan mudah berkosentrasi dengan teknik peta pikiran sehingga menimbulkan keinginan untuk memperoleh pengetahuan serta keinginan untuk berhasil. Berdasarkan uraian di atas, dapat diketahui bahwa metode Mind Map (peta pikiran) adalah metode yang dirancang oleh guru untuk membantu siswa dalam proses belajar, menyimpan informasi berupa materi pelajaran yang diterima oleh siswa pada saat pembelajaran, dan membantu siswa menyusun inti-inti yang penting dari materi pelajaran kedalam bentuk peta atau grafik sehingga siswa lebih mudah memahaminya.

\section{b. Langkah-langkah Penerapan Metode Mind Mapping}

Adapun Langkah-langkah Model

Pembelajaran Mind Mapping Menurut Swadarma (2013: 68) yaitu:

1) Guru menyampaikan tujuan pembelajaran,

2) Guru melemparkan satu topik yang berhubungan dengan materi,

3) Guru memberi penjelasan singkat dengan disertai tanya jawab,

Jurnal Ilmiah Mandala Education
4) Diakhir penjelasan guru memberi pertanyaan yang berhubungan dengan materi,

5) Untuk menjawabnya, siswa dikelompokkan dalam jumlah 4-5 orang,

6) Dalam setiap kelompok guru memberikan referensi (buku, artikel, majalah, koran) yang berhubungan dengan materi yang dibahas,

7) Setiap siswa dalam kelompoknya membuat mapping berdasarkan buku referensi yang dibaca,

8) Hasil mapping setiap siswa "dilebur" menjadi satu mapping besar,

9) Setiap kelompok mempresentasikan hasil mapping kelompoknya,

10) siswa menanggapi presentasi dengan guru sebagai moderator,

11) Guru menyimpulkan hasil belajar.

Sedangkan langkah-langkah pembelajaran Model Pembelajaran Mind Mapping menurut Muhmuddin (2009: 4) yaitu:

1) Menyampaikan kompetensi yang hendak dicapai kepada siswa pada awal pembelajaran

2) Guru mengemukakan terlebih dahulu konsep yang akan dipelajari.

3) Mengelompokkan siswa dalam kelompok kecil gengan jumlah anggota 2 hingga 3 orang

4) Kelompok diberi kesempatan untuk mencatat seluruh alternative jawaban yang diperoleh dari hasil diskusi

5) Tiap kelompok diarahkan untuk mencatat seluruh alternative jawaban yang dipeoleh dari hasil diskusi.

6) Masing-masing kelompok secara acak diberi kesempatan untuk kesempatan ini guru membacakan hasil diskusinya, pada kesempatan ini guru mencatat di papan tulis dan menggelompokkan jawaban tersebut berdasarkan beberapa criteria

7) Guru dan siswa bersama-sama membuat kesimpulan.

Berdasarkankedua pendapat di atas, maka dapat peneliti simpulkan bahwalangkah-langkah pembelajaran mind mapping sangat memudahkan guru untuk menyampaikan materi dan siswa juga dengan mudah memahami pelajaran dengan konsep 
ataupun model pembelajaran yang berbeda sehingga dalam tiap-tiap kelompok siswa bisa berinteraksi dan berdiskusi dari permasalahan yang diberikan dan membuat siswa lebih aktif dari biasanya dan menyampaikan hasil diskusinya lebih percaya diri.

\section{c. Kegunaan Metode Mind Mapping}

Menurut Michael Michalko (Buzan 2008: 25), metode Mind Mapping dapat dimanfaatkan atau berguna untuk berbagai bidang termasuk bidang pendidikan. Kegunaan metode Mind Mapping dalam bidang pendidikan, khususnya pada Sekolah Menengah Pertama kelas VIII antara lain:

1) Memberi pandangan menyeluruh pokok masalah,

2) Memungkinkan kita merencanakan rute atau kerangka pemikiran suatu karangan,

3) Mengumpulkan sejumlah besar data disuatu tempat,

4) Mendorong pemecahan masalah dengan kreatif.

Selain itu menurut Buzan metode Mind Mapping dapat bermanfaat untuk:

1) Merangsang bekerjanya otak kiri dan kanan secara sinergis (Gabungan),

2) Membebaskan diri dari seluruh jeratan aturan ketika mengawali belajar,

3) Membantu seseorang mengalirkan diri tanpa hambatan,

4) Membuat rencana atau kerangka cerita,

5) Mengembangkan sebuah ide,

6) Membuat perencanaan sasaran pribadi,

7) Memulai usaha baru,

8) Meringkas isi sebuah buku,

9) Fleksibel,

10) Dapat memusatkan perhatian,

11) Meningkatkan pemahaman,

12) Menyenangkan dan mudah diingat,

13) Cara Membuat Mind Mapping.

\section{d. Cara Membuat Mind Mapping}

Buzan (2009: 15-16), membuat Mind

Mapping membutuhkan imajinasi atau pemikiran, adapun cara pembuatannya adalah:

1) Mulailah dari tengah kertas kosong,

2) Gunakan gambar (simbol) untuk ide utama,

3) Gunakan berbagai warna.

4) Hubungan cabang-cabang utama ke gambar pusat,

5) Buatlah garis hubung yang melengkung,
6) Gunakan satu kata kunci untuk setiap garis,

7) Gunakan gambar.

Dalam membuat Mind Mapping juga diperlukan keberanian dan kreativitas yang tinggi. Variasi dengan huruf kapital, warna, garis bawah atau simbol-simbol yang menggambarkan poin atau gagasan utama. Menghidupkan Mind Mapping yang telah dibuat akan lebih mengesankan. Buzan telah menyusun sejumlah aturan yang harus diikuti agar Mind Mapping yang dibuat dapat memberikan manfaat yang optimal.

Aplikasi Mind Mapping menurut Buzan (2009: 15-16), dalam Pembelajaran dalam tahap aplikasi, terdapat empat langkah yang harus dilakukan proses pembelajaran berbasis Mind Mapping, yaitu:

1) Overview: Tinjauan menyeluruh terhadap suatu topik pada saat proses pembelajaran baru dimulai. Hal ini bertujuan untuk memberi gambaran umum kepada siswa tentang topik yang akan dipelajari. Khusus untuk pertemuan pertama pada setiap awal Semester, Overview dapat diisi dengan kegiatan untuk membuat Mind Mapping yang merupakan rangkuman dari seluruh topik yang akan diajarkan selama satu Semester yang biasanya sudah ada dalam Silabus. Dengan demikian, sejak awal siswa sudah mengetahui topik apa saja yang akan dipelajarinya sehingga membuka peluang bagi siswa yang aktif untuk mempelajarinya lebih dahulu di rumah atau di perpustakaan,

2) Preview: Tinjauan awal merupakan lanjutan dari Overview sehingga gambaran umum yang diberikan setingkat lebih detail daripada Overview dan dapat berupa penjabaran lebih lanjut dari Silabus. Dengan demikian, siswa diharapkan telah memiliki pengetahuan awal yang cukup mengenai sub-topik dari bahan sebelum pembahasan yang lebih detail dimulai. Khusus untuk bahan yang sangat sederhana, langkah Preview dapat dilewati sehingga langsung masuk ke langkah Inview,

3) Inview: Tinjauan mendalam yang merupakan inti dari suatu proses 
pembelajaran, di mana suatu topik akan dibahas secara detail, terperinci dan mendalam. Selama Inviewini, siswa diharapkan dapat mencatat informasi, konsep atau rumus penting beserta grafik, daftar atau diagram untuk membantu siswa dalam memahami dan menguasai bahan yang diajarkan,

4) Review: Tinjauan ulang dilakukan menjelang berakhirnya jam pelajaran dan berupa ringkasan dari bahan yang telah diajarkan serta ditekankan pada informasi, konsep atau rumus penting yang harus diingat atau dikuasai oleh siswa. Hal ini akan dapat membantu siswa untuk fokus dalam mempelajari-ulang seluruh bahan yang diajarkan di sekolah pada saat di rumah.

e. Kelebihan dan Kekurangan Metode Mind Mapping

1) Kelebihannya yaitu sebagai berikut:

a) Dapat mengemukakan pendapat secara bebas,

b) Dapat bekerja sama dengan teman lainnya,

c) Catatan lebih padat dan jelas,

d) Lebih mudah mencari catatan jika diperlukan,

e) Catatan lebih terfokus pada inti materi,

f) Mudah melihat gambaran keseluruhan,

g) Membantu Otak untuk: mengatur, mengingat, membandingkan dan membuat hubungan,

h) Memudahkan penambahan informasi baru,

i) Pengkajian ulang bisa lebih cepat dan setiap peta bersifat unik.

2) Kekurangannya yaitu sebagai berikut:

a) Hanya siswa yang aktif yang terlibat,

b) Tidak sepenuhnya siswa yang belajar,

c) Mind mapping siswa bervariasi sehingga guru akan kewalahan memeriksa mind mapping siswa.

2. Model Pembelajaran Kooperatif Tipe Team games tournamen (TGT)

a. Metode Pembelajaran Kooperatif tipe Team games tournamen (TGT)

Segala (2012:11) berpendapat bahwaTeam games tournament (TGT) adalah metode pembelajaran kooperatif yang mudah diterapkan, melibatkan aktifitas seluruh siswa tampa harus ada perbedaan status, melibatkan peran siswa sebagai tutor sebaya dan mengandung unsur permainan dan reinforcement.

Sedangkan menurut Purwanto (2011:22) bahwa pembelajaran kooperatif TGTmerupakan salah satu model pembelajaran kooperatif dengan di bentuk kelompok-kelompok kecil dalam kelas yang terdiri dari 4-5 siswa yang heterogen, baik prestasi akademik,jenis, ras ataupun etnis. Dalammodel pembelajaran kooperatif denganTGT digunakan turnamen akademik dimana siswa berkompetisi sebagai wakil dari timnya melawan anggota tim yang lain yang mencapai hasil atau prestasi serupa pada waktu lalu.

Berdasarkan kedua pendapatdi atas, maka dapat peneliti simpulkan bahwa pembelajaran kooperatif tipe TGTadalah pembelajaran yang dilakukan secara bersamasama atau berkelompok, siswa dalam satu kelas dijadikan kelompok-kelompok kecil yang terdiri dari 4-5 orang untuk memahami konsep yang difasilitasi oleh guru. Model pembelajaran kooperatif tipe TGTadalahmodel pembelajaran dengan setting kelompok-kelompok kecil dengan memperhatikan keberagaman anggota kelompok sebagai wadah, siswa bekerja sama dan memecahkan suatu masalah melalui interaksi sosial dengan teman sebayangnya, memberikan kesempatan pada siswauntuk mempelajari sesuatu dengan baik pada waktu yang bersamaan dan ia menjadi nara sumber bagi teman yang lain.

1) Komponen Pembelajaran Kooperatif Tipe Team Games Tournament (TGT).

Lie (2007:44) menjelaskan team games tounament (TGT) adalah salah satu tipe atau model pembelajaran kooperatif yang mudah diterapkan, melibatkan aktifitas seluruh siswa tanpa harus ada perbedaan status,melibatkan peran siswa sebagai tutor sebaya dan mengandung unsur permainan dan reinforcement.

Aktifitas belajar dengan permainan yang dirancang dalam model pembelajaran kooperatif tipe TGT memungkinkan siswa dapat belajar lebih rileksdisamping menumbuhkantanggungjawab, 
kerjasama,persaingan sehat dan kerlibatan belajar.

Menurut Slavin (2009:84) mengatakan ada 5 (lima) komponen utama dalam model pembelajaran kooperatif tipe team games tournament (TGT) adalah:

a) Penyajian kelas

Pada awal pembelajaran guru menyampaikan materi dalam penyajian kelas, biasanya dilakukan dengan pengajaran langsung atau dengan ceramah, diskusi yang dipimpin guru. Pada saat penyajian ini siswa harus benarbenar memperhatikan dan memahami materi yang disampaikan guru, karena akan membantu siswa bekerja lebih baik pada saat kerja kelompok dan pada saat game karena skor game akan menentukan skor kelompok.

b) Kelompok (team)

Kelompok biasanya terdiri dari 4 sampai 5 orang siswa yang anggotanyaheterogen dilihat dari prestasi akademik, jenis kelamin ras atau etnik. Fungsi kelompok adalah untuk lebih mendalami materi bersama teman kelompoknya dan lebih khusus untuk mempersiapkan anggota kelompok agar bekerja dengan baikdan optimal pada saat game.

c) Game

Game terdiri dari pertanyaan-pertanyaan yang dirancang untuk menguji pengetahuan yang didapat siswa dari penyajian kelas dan belajar kelompok. Kebanyakan game terdiri dari pertanyaanpertanyaan yang bernomor. Siswa memiliki kartu bernomor dan coba menjawab pertanyaan yang sesuai dengan nomor itu. Siswa yang menjawab benar pertanyaan itu akan mendapat skor. Skor ini yang nantinya dikumpulkan siswa untuk turnamen mingguan.

d) Tournamen

Biasanya tournamen dilakukan pada akhir minggu atau pada setiap unit setelah guru melakukan presentasi kelas dan kelompok sudah mengerjakan lembar kerja. Turnamen pertama guru membagi siswa beberapa meja turnamen.Tiga siswa tertiggi prestasinya di kelompokan pada meja 1, tiga siswa selanjutnya pada meja 2 dan selanjutnya.

e) Team recognize (penghargaan kelompok) Guru mengumumkan kelompok yang menang, masing masing team akan mendapat sertifikat atau hadiah apabila rata-rata skor memenuhi kriteria yang ditemukan. Team mendapat julukan "Super team" jika rata rata skornya lebih tinggi dari nilai 50 - 100 .

2) Kelebihan Penerapan Model Pembelajaran Kooperatif Tipe Team Games Tournament (TGT).

Kelebihan model pembelajaran kooperatif tipe TGT adalah sebagai berikut:

a) Model TGT tidak hanya membuat siswa yang cerdas (berkemampuan akademis tinggi) lebih menonjol dalam pembelajaran, tetapi siswa yang berkemampuan akademi lebih rendah juga ikut aktif dan mempunyai peranan yang penting dalam kelompoknya.

b) Dengan model pembelajaran ini, akan menumbuhkan rasa kebersamaan dan saling menghargai sesama anggota kelompoknya.

c) Dalam model pembelajaran ini, membuat siswa lebih bersemangat dalam mengikuti pelajaran. Karena dalam pembelajaran ini, guru menjanjikan sebuah penghargaan pada siswa atau kelompok terbaik.

d) Dalam pembelajaran siswa ini membuat siswa menjadi lebih senang dalam mengikuti pelajaran karena ada kegiatan permainan berupa tournamen dalam model ini.

Berdasarkan dari kelemahan Mind Mapping maka disenttingkan dengan Model Pembelajaran Kooperatif TipeTGT dari hasil settingan kelemahan Mind Mapping ditutupi oleh kelebihan dari Model Pembelajaran Kooperatif TipeTGT sehingga dalam proses pembelajaran terarah dengan menggunakan metode Mind Mapping untuk penyelesaian soal dan Model Pembelajaran Kooperatif TipeTGT dalam pembagian kelompoknya. 


\section{Motode Pembelajaran Mind Mapping bersetting Model Pembelajaran Kooperatif Tipe Team games tournamen (TGT)}

Berdasarkan pendapat para ahli maka langkah-langkah dalam pembelajaran Mind Mapping yaitu:

a. Guru menyampaikan tujuan pembelajaran

b. Guru melemparkan satu topik yang berhubungan dengan materi

c. Guru memberi penjelasan singkat dengan disertai tanya jawab

d. Diakhir penjelasan guru memberi pertanyaan berhubungan dengan materi

e. Untuk menjawabnya, siswa dikelompokkan dalam jumlah 4-5 orang

f. Dalam setiap kelompok guru memberikan referensi (buku, artikel, majalah, koran) yang berhubungan dengan materi yang dibahas

g. Setiap siswa dalam kelompoknya membuat mapping berdasarkan buku referensi yang dibaca

h. Hasil mapping setiap siswa "dilebur" menjadi satu mapping besar

i. Setiap kelompok mempresentasikan hasil mapping kelompoknya

j. Siswa menanggapi presentasi dengan guru sebagai moderator

k. Guru menyimpulkan hasil belajar

Pendapat dari para ahli maka langkahlangkah dalam pembelajaran Model Pembelajaran Kooperatif TipeTGTyaitu:

1. Penyajian kelas

2. Kelompok (gruop)

3. Game

4. Tournament

5. penghargaan kelompok

Dari langkah-langkah pembelajaran metode Mind Mapping dengan model pembelajaran kooperatif tipe $T G T$, maka peneliti akan mensettingkan keduanya untuk meningkat prestasi belajar siswa dan adapun langkah-langkahnya yaitu: Tabel 2.1: Langkah-langkah model pembelajaran Mind Mapping bersetting model pembelajaran kooperatif tipe Team Games Tournamen (TGT)

Jurnal Ilmiah Mandala Education

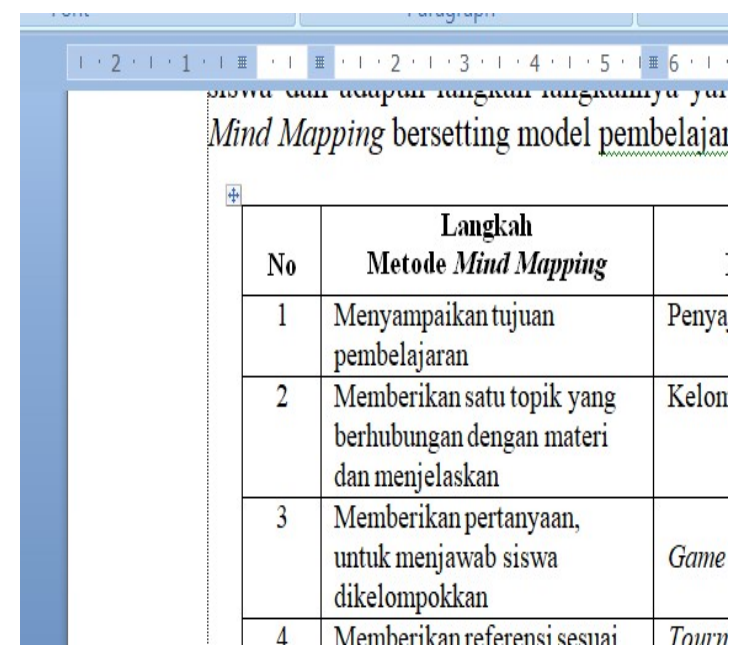

(Sumber: Swadarma (2013: 68) \& Slavin (2009: 84))

Adapun dari langkah-langkah model pembelajaran Mind Mapping bersetting model pembelajaran kooperatif tipe TGT maka uraian dan penjelasan dari tabel settingan diatas yaitu:

1. Pada awal pembelajaran guru menyampaikan materi yang akan dipelajari biasanya dilakukan dengan pengajaran langsung atau dengan ceramah. Pada saat penyajian ini siswa harus benar-benar memperhatikan dan memahami materi yang disampaikan guru.

2. Guru memberikan satu topik yang akan dibahas yang berhubungan dengan materi yang dijelaskan dan menerangkan secara terperincih bagaimana cara membuat mind mapping untuk penyelesaian soal sehingga siswa akan mudah memahami dan membuatnya.

3. Guru memberi tahu pada siswa bahwa diakhir penjelasan materi guru memberikan pertanyaan yang akan dijawab perkelompok dengan penyelesaian soalnya yang dianggap sebagai Game dengan menggunakan metode mind mapping yang sudah dijelaskan dan guru membagi kelompok biasanya terdiri dari 4 sampai 5 orang siswa yang anggotanyaheterogen, pembagian kelompok dilihat dari prestasi akademik, jenis kelamin ras atau etnik. Tujuannya untuk lebih mendalami materi bersama teman kelompoknya dan lebih khusus untuk mempersiapkan anggota 
kelompok agar bekerja dengan baikdan optimal pada saat game.

4. Dalam setiap kelompok guru memberikan referensi dan LKS untuk mempermudah sisa dalam menyelesaikan soal dengan menggunakan mind mapping.

5. Setiap siswa dalam kelompoknya diharuskan membuat mapping sebagai game dalam menyelesaikan soal yang diberikan sehingga dapat memenangkan tournament yang berlangsung dengan melalukan presentasi didepan kelas.

6. Tiap kelompok dalam tournament melakukan presentasi didepan kelas setelah tugas yang diberikan selesai diisi dan melakukan presentasi dengan baik dan benar.

7. Siswa dari kelompok lain diberi kesempatan untuk menanggapi hasil presentasi kelompok yang sedang presentasi didepan kelas setelah moderator memberikan kesempatan pada kelompok lain untuk memberikan pendapat, sanggahan ataupun pertanyaan untuk melengkapi hasil presentasi kelompok tersebut. Apabila permasalahan belum bisa terpecahkan oleh kelompokkelompok yang ada maka guru akan menjelaskan dan menyelesaikan permasalahan tersebut.

8. Guru memberikan penghargaan untuk kelompok yang menang, masing masing team akan mendapat sertifikat atau hadiah apabila rata-rata skor memenuhi kriteria yang ditemukan dan guru menyimpulkan hasil belajar. Dari hasil presentasi tiap kelompok maka guru mengumumkan kelompok yang menang yang telah menyelesaikan soal yang diberikan dengan menggunakan mind mapping dan mempresentasikan dengan sempurna, maka masing masing team akan mendapat sertifikat atau hadiah apabila rata-rata skor memenuhi kriteria yang ditemukan. Team mendapat julukan "Super team" jika rata rata skornya lebih tinggi dari nilai 50 100.

Berdasarkan settingan dari model dan metode di atas maka peneliti menyimpulkan mahwa dengan menggunakan mind mapping sebagai metode untuk penyelesaian soal yang diberikan dengan bersetting model pembelajaran tipe TGT sangat bermanfaat dan membuat siswa lebih aktif dari biasanya dan untuk menyesaikan tugas yang diberikan tiap kelompok dapat mengerjakan bersama-sama dengan baik, dan dengan menggunakan metode ini akan meningkatkan prestasi belajar siswa dalam pelajaran matematika.

\section{Prestasi Belajar}

a. Pengertian Prestasi Belajar

Prestasi belajar merupakan istilah yang tidak asing lagi dalam dunia pendidikan. Istilah tersebut lazim digunakan sebagai sebutan dari penilaian dari hasil belajar. Dimana penilaian tersebut bertujuan melihat kemajuan belajar siswa dalam hal penguasaan materi pengajaran yang telah dipelajarinya sesuai dengan tujuan yang telah ditetapkan. Prestasi belajar terdiri dari dua kata, yakni prestasi dan belajar. Prestasi belajar digunakan untuk menunjukkan hasil yang optimal dari suatu aktivitas belajar sehingga artinya pun tidak dapat dipisahkan dari pengertian belajar.

Prestasi merupakan hasil yang telah dicapai dari usaha yang telah dilakukan dan dikerjakan atau dalam definisi yang lebih singkat bahwa prestasi adalah hasil yang telah di capai (dilakukan dan dikerjakan). Senada dengan pengertian di atas, prestasi adalah hasil yang telah di capai dari apa yang dikerjakan yang sudah diusahakan (Nawawi, 2010: 20).

Sedangkan dalam buku psikologi belajar dijelaskan belajar adalah suatu usaha yang dilakukan individu untuk memperoleh suatu perubahan tingkahlaku yang baru secara keseluruhan sebagai hasil dari pengalaman individu itu sendiri dengan lingkungannya, Djamarah (2012:13).

Berdasarkan pendapat beberapa ahli dapat dipahami bahwa hasil belajar merupakanhasil dari suatu usaha yang telah dilakukan secara sungguh-sungguh pada suatu aktivitas atau pekerjaan tertentu sehingga diperoleh suatu hasil yang maksimal dalam waktu tertentu. Dengan kata lain segala sesuatu yang telah dicapai sebagai hasil dari interaksi dan aktualisasi dirinya dengan lingkungannya serta pengalaman dan latihan belajar yang telah dilalui (dilakukan) baik di 
sekolah maupun di dilingkungan masyarakat yang lebih luas sehingga dari hasil belajar yang didapat maka memberikan perubahan dari dirinya sehingga bermanfaat bagi dirinya sendiri, orang tua maupun orang lain yang berada disekitarnya .

Prestasi belajar matematika menurut Arifin (2009: 3) yang menyatakan bahwa prestasi adalah hasil dari kemampuan, keterampilan dan sikap seseorang dalam menyelesaikan suatu hal. Di dalam teori prestasi menurut arifin yakni suatu usaha yang telah dilaksanakan menurut batas usaha tersebut. Prestasi merupakan akhir dari usaha yang melalui proses pendidikan dan pelatihan tertentu yang telah dicapai. Prestasi yang dicapai sering mendatangkan konsekuensikonsekuensi berupa imbalan-imbalan yang bersifat material psikologis ataupun sosial.

Menurut Tirtonogoro (2010: 43) yang menyatakan bahwa prestasi adalah penilaian hasil usaha kegiatan belajar mengajar yang dalam bentuk simbol, angka, huruf, atau kalimat yang dapat mencerminkan hasil usaha yang sudah dicapai oleh anak dalam periode tertentu. Jadi, Menurut para ahli dapat disimpulkan bahwa prestasi belajar matematika adalah suatu hasil atau pencapaian yang berasal dari usaha belajar siswa yang dapat dinyatakan kedalam bentuk nilai-nilai, yang dimana nilai-nilai tersebut dapat mengambarkan pencapaian dari setiap siswa sebagai wujud hasil belajar matematika pada periode tertentu.

b. Tingkatan Prestasi Belajar

Prestasi belajar sebagai hasil dari suatu kegiatan belajar yang dilakukan oleh siswa baik di sekolah tentu memiliki tingkatan. Adapun tingkatan hasil belajar siswa tersebut, dijelaskan bahwa keberhasilan belajar siswa dapat dilihat dari beberapa tingkatan, dimana setiap proses belajarmengajar yang dilakukan sudah barang tentu menghasilkan hasil atau prestasi belajar.

Tingkat keberhasilan belajar (prestasi belajar) siswa dapat diklasifikasikan menjadi beberapa bagian yaitu:

1) Hasil belajar yang istimewa

Dalam buku guru dan siswa dalam interaksi edukatif dijelaskan Hasil (prestasi) belajar yang istimewa adalah hasil belajar yang apabila seluruh bahan atau materi pelajaran yang diajarkan tersebut dapat dikuasai oleh siswa (Djamarah dan Zain, 2012:106).

Jadi, dapat dipahami bahwa prestasi atau hasil belajar yang istimewa merupakan hasil belajar yang diperoleh oleh siswa apabila seluruh bahan pelajaran yang diajarkan dapat dikuasai dan dipahami.

2) Hasil yang baik sekali atau optimal

Dalam buku guru dan siswa dalam interaksi edukatif dijelaskan hasil belajar yang baik sekali adalah hasil belajar yang apabila sebagaian besar (76\% sampai dengan $99 \%$ ) bahan materi pelajaran yang diajarkan dapat dikuasai oleh siswa (Djamarah dan zain, 2012: 107). Jadi, dapat dipahami bahwa dikatan hasil belajar yang baik sekali apabila siswa dapat menguasai dan memahami sebagaian besar dari materi pelajaran yang diajarkan oleh guru di sekolah.

3) Hasil yang baik atau minimal

Dalam buku guru dan siswa dalam interaksi edukatif dijelaskan hasil belajar yang baik atau minimal adalah hasil belajar yang apabila bahan pelajaran yang diajarkan hanya $60 \%$ sampai dengan $75 \%$ saja yang dikuasai oleh siswa (Djamarah dan Zain, 2012: 108). Jadi, hasil belajar yang baik atau minimal ini apabila bahan pelajaran yang diajarkan oleh guru dapat dikuasai di atas $60 \%$ atau di bawah $75 \%$ oleh siswa.

4) Hasil yang kurang

Dalam buku guru dan siswa dalam interaksi edukatif dijelaskan hasil belajar yang kurang adalah hasil belajar yang apabila bahan atau materi pelajaran yang diajarakan kurang dar $60 \%$ dikuasai oleh siswa (Djamarah dan zain, 2012: 108). Jadi, hasil belajar yang kurang dapat diketahui dari hasil penguasaan materi pelajaran yang diajarkan oleh guru, dimana materi/bahan pelajaran yang dikuasai kurang dari $60 \%$ oleh siswa.

Dari semua uraian di atas, prestasi belajar siswa memiliki tingkatan penguasaan materi pelajaran yang bervariasi seperti istimewa, baik sekali, baik dan kurang. Prestasi belajar yang dicapai oleh siswa tentu berbeda-beda sebab tidak semua siswa memiliki kemampuan yang sama tetapi 
diantara siswa memiliki perbedaan antara yang satu dengan yang lainnya.

c. Faktor-faktor yang Mempengaruhi Prestasi Belajar

Dalam buku belajar dan faktorfaktor yang mempengaruhinya dijelaskan faktor-faktor yang mempengaruhi prestasi belajar siswa dapat dibedakan menjadi dua faktor yaitu faktor Internal yaitu faktor dari dalam diri siswa dan faktor eksternal yaitu faktor dari luar diri siswa (Slameto,2013:57).

Adapun uraian masing-masing faktor yang mempengaruhi hasil belajar pada diri siswa tersebut sebagai berikut:

1. Faktor internal antara lain:

a) Intelegensi siswa

Intelegensi adalah kemampuan psikofisik untuk mereaksi rangsangan atau menyesuaikan diri dengan lingkungan dengan cara yang tepat (Sudjana, 2015:39). Jadi, intelegensi sangat dibutuhkan dalam proses belajar, untuk mencapai tujuan dan hasil belajar yang optimal.

b) Bakat siswa

Bakat adalah kemampuan (potensi) yang dimiliki oleh seseorang untuk mencapai keberhasilan pada masa yang akan datang (Muhibbin, 2013: 136). Jadi, bakat adalah kemampuan siswa untuk belajar baik dalam memahami, menghayati maupun mengkaji bahan pelajaran yang diajarkan oleh guru di sekolah.

c) Minat Belajar

Minat merupakan kecenderungan atau kegairahan yang tinggi atau keinginan yang besar terhadap sesuatu. Menurut Slameto dalam bukunya (Slameto, 2013: 57) mengemukakan minat adalah kecenderungan yang tepat untuk memperhatikan dan mengenang beberapa kegiatan.

Jadi, minat adalah keinginan siswa untuk belajar dalam bidang studi tertentu. Seperti siswa yang menaruh minat besar terhadap pelajaran matematika akan memusatkan perhatian yang intensif terhadap materi yang diajarkan.

2. Faktor eksternal antara lain

a) Lingkungan keluarga antara lain:

(1). Suasana rumah

Hubungan keluarga yang harmonis dapat menjadikan anak belajar dengan baik.
Sedangkan suasana rumah yang terlalu gaduh atau terlalu ramai tidak akan memberikan suasana bagi anak untuk belajar dengan baik (Slameto, 2013: 56).

(2). Keadaan sosial

Dalam buku strategi belajar mengajar dijelaskan Kegiatan belajar anak kadang memerlukan sarana yang cukup mahal dan tidak terjangkau oleh keluarga. Keadaan sosial tersebut tidak memungkinkan untuk memenuhi belajar anak, sehingga kondisi ini dapat menghambat anak dalam belajarnya (Ahmadi, 2015: 88).

(3). Lingkungan sosial

Dalam buku psikologi belajar dijelaskan lingkungan sosial adalah lingkungan sekitar belajar siswa seperti orang tua/keluarga yang banyak mempengaruhi belajar anak, termasuk sifat orang tua dan ketegangan keluarga sehingga dapat memberikan dampak yang baik dan buruk terhadap hasil yang di capai (Muhibbin, 2013: 153).

Dengan demikian lingkungan belajar baik maka dapat menjadikan hasil belajar anak menjadi baik. Begitu pula sebaliknya, lingkungan belajar siswa jelek akan berdampak pula pada sikap dan prilaku siswa dalam kehidupan sehari-hari.

b) Lingkungan sekolah antara lain:

(1). Interaksi guru dan siswa

Kurangnya interaksi guru dengan siswa secara lazim menyebabkan proses belajar mengajar kurang lancar, dan akan mempengaruhi minat belajar siswa karena apabila interaksi guru dengan siswa kurang baik atau monoton maka dapat juga menjadi salah satu penyebab rendahnya minat bagi siswa (Slameto, 2013: 57).

(2). Cara penyampaian

Cara penyajian bahan atau materi pelajaran juga dapat mempengaruhi rendahnya minat dan gairah belajar siswa di sekolah. Dalam penyajian bahan pelajaran, jika guru selalu mengajar dengan metode konvensional dapat menyebabkan siswa menjadi bosan, mengantuk, pasif, dan hanya berfungsi sebagai notulis dari ucapan guru di depan kelas (Slameto, 2013: 58).

(3). Media 
Media adalah suatu perantara (penyalur) informasi dalam proses belajar mengajar (Slameto, 2013: 58). Jadi, media mutlak diperlukan dalam membantu menunjang lancarnya belajar siswa di sekolah, seperti buku-buku di perpustakaan, lembar kerja siswa dan media pendidikan.

(4). Keterampilan mengajar guru

Dalam buku guru dan siswa dalam interaksi edukatif dijelaskan keterampilan mengajar guru yaitu suatu kemampuan guru dalam menciptakan dan memelihara kondisi belajar yang optimal dan berupaya mengendalikannya apabila terjadi gangguan dalam proses belajar mengajar sehingga tercapai tujuan pembelajaran (Djamarah, 201:5 172). Dengan demikian keterampilan mengajar guru merupakan salah satu faktor yang memiliki hubungan yang erat dengan peningkatan hasil belajar siswa. Sebab guru yang memiliki terampilan mengajar yang baik tentu sangat memungkinkan meningkatnya hasil belajar siswa di sekolah.

Adapun komponen-komponen yang menentukan keberhasilan belajar siswa dalam dalam pembelajaran matematika juga adalah sebgai berikut:

1) Tujuan

Tujuan adalah suatu cita-cita yang ingin dicapai dari pelaksanaan suatu kegiatan. Tidak ada suatu kegiatan yang diprogramkan tanpa tujuan, karena hal itu adalah suatu hal yang tidak memiliki kepastian dalam menentukan ke arah mana kegiatan itu akan dibawa (Djamarah dan Zain, 2012: 28).

Jadi dari uraian di atas dapat dipahami bahwa tujuan merupakan komponen pertama yang harus ditetapkan dalam proses pembelajaran yang berfungsi sebagai indikator keberhasilan proses belajar mengajar.

2) Bahan Pelajaran

Bahan merupakan bagian inti dari bahan yang akan disampaikan kepada siswa. Kaitannya dengan hal ini dijelaskan bahwa bahan belajar adalah "substansi (isi) pelajaran yang akan disampaikan dalam proses edukatif. Tanpa bahan pelajaran proses belajar mengajar tidak akan berjalan" (Djamarah, 2015: 17).

Jurnal Ilmiah Mandala Education
Jadi dapat dipahami bahwa bahan pelajaran adalan unsur inti dalam kegiatan belajar mengajar, sebab bahan pelajaran merupakan inti dari apa yang disampaikan dalam proses belajar mengajar yang dilakukan di sekolah.

3) Kegiatan Belajar-mengajar

Kegiatan belajar-mengajar adalah inti kegiatan dalam pendidikan. Segala sesuatu yang telah diprogramkan akan dilaksanakan dalam proses belajar-mengajar (Djamarah, 2015: 18). Dengan demikian kegiatan belajar mengajar merupakan salah satu komponen yang melibatkan guru dan siswa dalam suatu intraksi normatif untuk bersama-sama mencapai tujuan pendidikan dan pembelajaran.

4) Metode

Adapun yang dimaksud dengan metode adalah "suatu cara yang dipergunakan untuk mencapai tujuan yang ditetapkan" (Djamarah dan Zain, 2012: 53). Lebih jauh dijelaskan bahwa "Metode adalah langkah kegiatan yang dilakukan oleh guru dalam membantu siswa mencapai tujuan yang ditentukan”. (Darmadi, 2011: 59).

Berdasarkan kedua pengertian di atas, metode adalah suatu yang digunakan oleh guru dalam menyampaikan materi pelajaran pada proses kegiatan belajar-mengajar. Dalam kegiatan belajar-mengajar, metode sangat diperlukan oleh guru dan penggunaannya harus digunakan bervariasi sesuai dengan tujuan yang ingin dicapai setelah pelajaran berakhir.

Jika seorang guru tidak menguasai satupun metode mengajar yang telah dirumuskannya, maka tidak akan dapat melaksanakan tugasnya dengan baik, sehingga dalam kegiatan belajar-mengajar seorang guru harus menguasai metode pengajaran dan tidak harus terpaku dengan menggunakan satu metode saja, tetapi harus menggunakan metode yang bervariasi agar menarik perhatian siswa dan dapat membangkitkan minat belajar siswa.

5) Alat

Alat juga merupakan salah satu komponen dalam proses pembelajaran. Kaitannya dengan hal ini dijelaskan bahwa "Alat adalah segala sesuatu yang dapat 
digunakan dalam rangka mencapai tujuan pengajaran" (Djamarah, 2013: 17). Lebih jauh dijelaskan "Bahwa dalam kegiatan belajarmengajar alat mempunyai fungsi, yaitu alat sebagai perlengkapan alat sebagai pembantu mempermudah usaha mencapai tujuan dan alat sebagai tujuan" (Djamarah dan Zain. 2013: 54).

Berdasarkan pengertian dan fungsi alat tersebut jelas bahwa alat tidak dapat diabaikan dalam program pengelolaan pengajaran. Karena apapun bentuk bahan pelajaran yang akan disampaikan oleh guru dalam kegiatan belajar-mengajar kalau tidak menggunakan alat, maka akan menghadapi kesulitan dan tujuan pembelajaran yang diinginkan sulit tercapai. Dalam proses kegiatan belajar-mengajar, alat tidak hanya berupa material saja akan tetapi ada yang berupa non material.

6) Sumber Pelajaran

Adapun yang dimaksud dengan sumber pelajaran adalah "segala sesuatu yang dipergunakan sebagai tempat belajar (Djamarah dan Zain, 2013: 55). Sedangkan menurut Sardiman dalam Djamarah dan Zain (2013: 56) bahwa "Sumber-sumber bahan pelajaran sesungguhnya banyak sekali dimana-mana misalnya, di madrasah, di halaman, dipusat kota, di pedesaan, dan sebagainya. Pemanfaatan sumber-sumber pelajaran tersebut tegantung pada kreativitas guru, waktu, biaya serta kebijakan-kebijakan lainnya".

Berdasarkan penjelasan di atas, dapat dipahami bahwa sumber belajar itu merupakan segala sesuatu yang dapat dipergunakan dan bermanfaat untuk dijadikan sebagai sumber belajar baik di dalam sekolah maupun di luar sekolah.

7) Evaluasi

Evaluasi dapat diartikan sebagai suatu tindakan atau suatu proses untuk menentukan nilai segala sesuatu dalam dunia pendidikan atau sesuatu yang berhubungan dengan dunia pendidikan (Djamarah dan Zain, 2013: 58).

Evaluasi menurut Kumano (2014: 22) merupakan penilaian terhadap data yang dikumpulkan melalui kegiatan asesmen.

Berdasarkan beberapa pengertian di atas, dapat dipahami bahwa evaluasi adalah sauatu kegiatan guru untuk mengetahui sejauh mana perubahan yang terjadi pada diri siswa. Perubahan tersebut tidak hanya pada aspek kognitif atau pengetahuannya saja, tetapi yang lebih penting adalah perubahan aspek afektif dan psikomotorik pada diri siswa dalam kehidupan sehari-hari terutama dalam meningkatkan minat belajarnya baik di sekolah maupun di luar sekolah.

\section{METODE PENELITIAN}

Adapun jenis penelitian yang peneliti gunakan adalah jenis penelitian eksperimen. Penelitian eksperimen adalah suatu penelitian yang berusaha mencari pengaruh variabel tertentu terhadap variabel lain dalam kondisi yang terkontrol (Darmadi, 2011:17).

Dalam penelitian eksperimen, peneliti membagi subjek yang diteliti menjadi dua grup, yaitu grupeksperimen atau yang memperoleh perlakuan dan grup kontrol yang tidak memperoleh perlakuan. Penelitian eksperimen, karena peneliti sudah melakukan kegiatan mengontrol, maka hasil penelitian dapat menentukan hubungan sebab akibat (Darmadi, 2011:36).

Metode penelitian ini adalah eksperimen yang akan mengkaji pengaruh model pembelajaran mind mapping bersettingpembelajaran kooperatif tipe TGT untuk meningkatkan prestasi belajar siswa. Dalam hal ini terdapat kelas eksperimen yang diterapkan pembelajaran matematika dengan model mind mapping bersetting pembelajaran kooperatif tipe TGT dan kelas kontrol dengan metode pembelajaran konvensional.

Rancangan umum penelitian dibuat rincian, pada tahap awal pembelajaran kedua kelas tersebut akan diberikan pre-test pada awal dan post-test pada akhir pembelajaran merupakan sampel penelitian disimbolkan dengan (X) selama empat kali $(4 \mathrm{x})$ pertemuan dan pengukuran dilakukan sesudah pengamatan diberikan. Pada kelas eksperimen diterapkan pengaruh pendekatan metode mind mapping bersetting pembelajaran kooperatif tipeTGT sedangkan pada kelas kontrol diterapkan metode pembelajaran konvensional. Pada akhir pembelajaran dilakukan tes untuk meningkatkan prestasi belajar siswa. Tes dilakukan di kelas kontrol dan kelas 
eksperimen dengan soal yang sama. Soal tes yang diberikan kepada kelas sampel adalah soal yang telah valid. Data yang telah dianalisis sesuai dengan statistik.

Tabel 3.1 Desain Penelitian

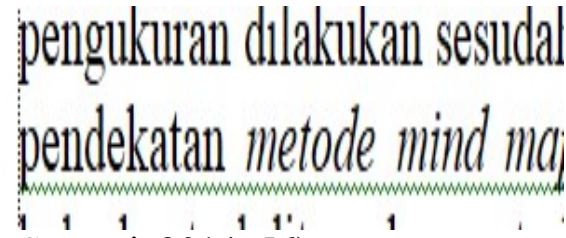

(Sumber: Sontani, 2014: 56)

Keterangan:

$\mathrm{B}_{\mathrm{e}}=$ Pemberian pre-test pada kelas eksperimen

$\mathrm{B}_{\mathrm{k}}=$ Pemberian post-test pada kelas kontrol

$\mathrm{X}_{\mathrm{e}}=$ Pemberian pre-test pada kelas eksperimen

$\mathrm{X}_{\mathrm{k}}=$ Pemberian post-test pada kelas control

$\mathrm{X}_{\mathrm{e}}=$ Pemberian pembelajaran dengan model mind mapping bersetting pembelajaran kooperatif tipe TGT

$\mathrm{X}_{\mathrm{k}}=$ Pemberian pembelajaran dengan metode pembelajaran ceramah

Tempatdan waktu penelitian sangat penting ditentukan agar target dan tujuan penelitian dapat dicapai sebagaimana yang diharapkan. Tempat atau lokasi penelitian ini dilakukan di SMPN 1 Palibelo tahun ajaran 2017/2018 yang beralamat di Jalan Lintas Palibelo-TekeKabupaten Bima. Pelaksanaan penelitian dilakukan pada tanggal 24 Juni 24 Agustus 2017.

Populasi adalah keseluruhan subjek penelitian (Suharsimi, 2012: 108). Lebih jauh dijelaskan populasi adalah wilayah generalisasi yang terdiri atas obyek atau subyek yang mempunyai kualitas dan karakteristik tertentu yang ditetapkan oleh peneliti untuk dipelajari dan kemudian ditarik kesimpulannya (Sugiono, 2009: 90). Adapun populasi dalam penelitian ini adalah semua siswa kelas VIII SMP Negeri 1 Palibelo tahun ajaran 2017/2018. Sebanyak 125 orang siswa dapat dilihat pada tabel di bawah ini:
Table. 3.2 Jumlah Populasi Dalam Penelitian

\begin{tabular}{|c|c|c|c|c|}
\hline \multirow{2}{*}{ No } & \multirow{2}{*}{ Kelas } & \multicolumn{2}{|c|}{ Jumlah Siswa } & \multirow{2}{*}{ Jumlah } \\
\cline { 3 - 4 } & & Putra & Putri & \\
\hline 1 & VIII A & 13 & 14 & 25 \\
\hline 2 & VIII B & 14 & 11 & 25 \\
\hline 3 & VIII C & 13 & 12 & 25 \\
\hline 4 & VIII D & 13 & 12 & 25 \\
\hline 5 & VIII E & 12 & 13 & 25 \\
\hline \multicolumn{2}{|c|}{ Jumlah } & 65 & 60 & 125 \\
\hline
\end{tabular}

(Sumber: Arsip Siswa Kelas VIII SMPN 1 Palibelo Tahun Ajaran 2017)

Sampel adalah sebagian dari atau wakil populasi yang diteliti (Arikunto, 2010: 131). Adapun pengambilan sampel dalam penelitian ini dilakukan secara random sampling. Hal ini dilakukan dengan pertimbangan bahwa siswa mendapatkan materi pokok pada kurikulum yang sama, siswa yang menjadi objek penelitian duduk pada tingkat kelas yang sama yaitu kelas VIII, siswa mendapatkan waktu pelajaran yang sama, dan dalam pembagian kelas tidak terdapat kelas unggulan. Dengan menggunakan teknik pengambilan tersebut, secara acak dipilih dua kelas sampel sebagai kelas eksperimen yaitu kelas VIII $_{\mathrm{B}}$ dan kelas kontrol yakni kelas VIII $\mathrm{E}_{\text {. }}$

Instrumen yang digunakan dalam penelitian ini berupa tes kemampuan meningkatkan prestasi belajar dan dokumentasi yang masing-masing akan dijelaskan sebagai berikut:

1. Instrumen Tes

Instrument tes dalam penelitian ini adalah tes untuk meningkatkan prestasi belajar siswa yang akan dilakukan pada kelas eksperimen dan kelas kontrol berupa tes awal (pre-test) dan tes akhir (post-test) dengan tujuan mendapatkan data awal dan akhir. Tes yang diberika berupa tes uraian dengan jumlah butir soal 10, terdapat 5 butir soal untuk pre-tes dan 5 butir soal untuk post-tes yang memiliki indikator dan kisi-kisi soal yang sama.

2. Dokumentasi

Dokumentasi berarti cara mengumpulkan data dengan mencatat data yang sudah ada (Rianto, 2013: 83) digunakan untuk memperoleh data mengenai nama dan jumlah siswa yang menjadi anggota populasi serta untuk menentukan anggota sampel pada siswa kelas VIII. 
3. Lembar Observasi

Observasi merupakan metode pengumpulan data yang dilakukan dengan cara mengamati dan mencatat secara sistematis gejala-gejala yang diselidiki (Supardi, 2016: 88) untuk mengetahui data tentang keterklaksanaan rencana pelaksanaan pembelajaran (RPP), data pemahaman konsep siswa selama proses belajar mengajar karena ada beberapa indikator yang diamati seperti partisipasi siswa dalam mengikuti pelajaran, interaksi siswa dengan siswa, interaksi siswa dengan guru.

Untuk mengatahui valid atau tidak suatu instrumen maka perhatikan jenis validitas yaitu dengan Validitas Konstruk (Construct validity)Menurut Djaali dan Pudji (2015: 89) validitas konstruk adalah validitas yang mempermasalahkan seberapa jauh itemitem tes mampu mengukur apa yang benarbenar hendak diukur sesuai dengan konsep khusus atau definisi konseptual yang telah ditetapkan.Validitas konstruk biasa digunakan untuk instrumen-instrumen yang dimaksudkan mengukur variabel-variabel konsep, seperti instrumen untuk mengukur sikap, minat, konsep diri, motivasi berprestasi, dan lain-lain, maupun yang sifatnya performansi (penampilan) maksimum seperti instrumen untuk mengukur bakat (tes bakat), intelegensi (kecerdasan intelekual), kecerdasan emosional dan lain-lain.

Menentukan validitas konstruk suatu instrumen harus dilakukan proses penelaahan teoritis dari suatu konsep dari variabel yang hendak diukur, mulai dari perumusan konstruk, penentuan dimensi dan indikator, sampai kepada penjabaran dan penulisan butir-butir item instrumen. Perumusan konstruk harus dilakukan berdasarkan sintesis dari teori-teori mengenai konsep variabel yang hendak diukur melalui proses analisis dan perbandingan yang logik dan cermat.

\section{Analisis Deskripsi}

Analisis deskripsi digunakan untuk mendeskripsikan data. Datayang dideskripsikan pada penelitian ini berupa skor pre-test dan post-testdari kelas eksperimen dan kelas kontrol. Dari data tersebut dihitungrata-rata, variansi, dan simpangan baku.Perhitungan rata-rata, variansi, dan simpangan baku menggunakanrumus dilakukan dengan bantuan software SPSS 16 of windows dan Microsoft officel excelsebagai berikut:

Tabel 3.3 Rumus Analisis Deskripsi

\begin{tabular}{|c|c|}
\hline Rata-rata (1alpole 1995: 24) & $\bar{x}={\frac{1}{n_{\overline{i=1}}^{n}}}^{n} x_{i}$ \\
\hline $\begin{array}{c}\text { Ragam / Variansi } \\
\text { (Walpole 1995:24) }\end{array}$ & $S^{2}=\frac{1^{n}{ }^{n}}{n-1_{\bar{i}=1}}\left(\bar{x}_{i}-\bar{x}\right)^{2}$ \\
\hline Simpangan baku & $\begin{array}{c}S^{2}=\frac{\overline{S^{2}}}{n} \\
=1^{1^{n}} x_{i}\end{array}$ \\
\hline
\end{tabular}

(Sumber Nirmala dyah, 2015: 61)

\section{Analisis Statistik Inferensial}

Analisis inferensial yaitu untuk pengujian hipotesis. Sebelum pengujian hipotesis dilakukan uji persyaratan pembuktian hipotesis, adapun uji yang dibutuhkan dalam analisis ini berupa uji normalitas dan uji homogenitas. dimana uji normalitas dan uji homogenitas ini dibagi dalam 2 uji asumsi yaitu, uji asumsi sebelum perlakuan (pre-test) dan uji asumsi sesudah perlakuan (post-test). Ada pun penjelasannya sebagai berikut:

\section{Uji Asumsi Sebelum Perlakuan (Pre-Test)} a. Uji Normalitas

Pengujian normalitas dilakukan untuk mengetahui bahwa data awal sampel yang diambil berasal dari populasi yang berdistribusi normal atau tidak, digunakan Rumus kalmogorof-Smirnovmenurut Engineering Statistics Hanbook (2009: 10), dilakukan dengan bantuan software SPSS 16 of windows dan Microsoft officel excel:

$D=\max _{1 \leq i \leq N}\left(F\left(Y_{i}\right)-\frac{i-1}{N}, \frac{i}{N}-F\left(Y_{i}\right)\right)$

Keterangan:

$\mathrm{F}=$ Distribusi kumulatif teoritis dari distribusi yang diuji

berdistribusi kontinu

$\mathrm{N} \quad=$ Banyak Sampel

$i \quad=$ Jumlah kurang dari $Y_{i}$

$Y_{i} \quad=$ Nilai terkecil hingga terbesar

$\frac{1}{N} \quad=$ Nilai data.

\section{b. Uji Homogenitas}

Jika hasil uji normalitas diperoleh bahwa data awal sampel yang diambil berasal dari populasi yang berdistribusi normal sehingga dapat dilanjutkan dengan uji homogenitas. Uji homogenitas dilakukan untuk membuktikan apakah kedua sampel 
yang menjadi objek peneliti homogen atau tidak, Rumus yang digunakan (Imam Gozali, 2013: 205)

$F_{\text {Hitung }}=\frac{S_{2}^{2}}{S_{1}^{2}}$

Keterangan:

$S_{1}^{2}=$ Variansi data prestasi belajar siswa dari kelas eksperimen

$S_{2}^{2}=$ Variansi data prestasi belajar siswa dari kelas kontrol.

Kriteria pengujian:

Jika : $\mathrm{F}_{\text {hitung }}>\mathrm{F}_{\text {tabel, }}$, tidak homogen

Jika : $\mathrm{F}_{\text {hitung }}<\mathrm{F}_{\text {tabel }}$, homogen

Taraf signifikan $(\alpha)=5 \%$

\section{Uji Asumsi Sesudah Perlakuan (Pro-Test)}

\section{1) Uji Normalitas}

Pengujian normalitas dilakukan untuk mengetahui bahwa data awal sampel yang diambil berasal dari populasi yang berdistribusi normal atau tidak, digunakan Rumus kalmogorof-Smirnov Engineering Statistics Hanbook (2009: 10), dilakukan dengan bantuan software SPSS 16 of windows dan Microsoft officel excel:

$D=\max _{1 \leq i \leq N}\left(F\left(Y_{i}\right)-\frac{i-1}{N}, \frac{i}{N}-F\left(Y_{i}\right)\right)$

Keterangan:

$\mathrm{F}=$ Distribusi kumulatif teoritis dari distribusi yang diuji berdistribusi kontinu

$\mathrm{N}$ = Banyak Sampel

$i=$ Jumlah kurang dari $Y_{i}$

$Y_{i}=$ Nilai terkecil hingga terbesar

$\frac{1}{N}=$ Nilai data.

\section{2) Uji Homogenitas}

Jika hasil uji normalitas diperoleh bahwa data awal sampel yang diambil berasal dari populasi yang berdistribusi normal sehingga dapat dilanjutkan dengan uji homogenitas. Uji homogenitas dilakukan untuk membuktikan apakah kedua sampel yang menjadi objek peneliti homogen atau tidak,Rumus yang digunakan (Imam Gozali, 2013: 205)

$F_{\text {Hitung }}=\frac{S_{2}^{2}}{S_{1}^{2}}$

Keterangan:

$S_{1}^{2}=$ Variansi data kemampuan komunikasi matematis dari kelaseksperimen

$S_{2}^{2}=$ Variansi data kemampuan komunikasi matematis dari kelas kontrol.
Kriteria pengujian:

Jika : $\mathrm{F}_{\text {hitung }}>\mathrm{F}_{\text {tabel, }}$, tidak homogen

Jika : $\mathrm{F}_{\text {hitung }}<\mathrm{F}_{\text {tabel, }}$, homogen

Taraf signifikan $(\alpha)=5 \%$

\section{3) Uji Hipotesis}

Pengaruh atau tidaknya metode pembelajaran metode mind mapping bersetting model pembelajaran kooperatif tipe TGT dari prestasi belajar siswa. Untuk melihat pengaruh metode pembelajaran metodeMind Mappingbersetting model pembelajaran kooperatif tipe TGT dapat menggunakan uji one sampel t-test yang diperoleh dari data post-tets. Adapun format uji $t$ (one sampel t-test) sebagai berikut: (Sugiyono, 2015: 115).

$t=\frac{\bar{d}-\mu_{0}}{S / \sqrt{n}}$

Keterangan:

$\bar{d}$ : Rata-rata sampel

$\mu_{0}$ : Rata-rata yang ditetapkan

$S$ : Varian sampel

$n$ : Banyaknay anggota sampel

Kriteria keputusan yaitu $\mathrm{H}_{0}$ ditolak apabila $t_{\text {hitung }}>t_{(0,05: n-1)}$ Hipotesis

$\mathrm{H}_{0}: \mu$ (MetodeMind Mappingbersetting model pembelajaran kooperatif tipe TGT tidak mempengaruhi prestasi belajar siswa).

Ha: $\mu$ (MetodeMind Mappingbersetting model pembelajaran kooperatif tipe TGT mempengaruhi prestasi belajar siswa).

Untuk mengetahui secara rinci uji statistik maka perhatikan skema di bawah ini agar mudah dimengerti.

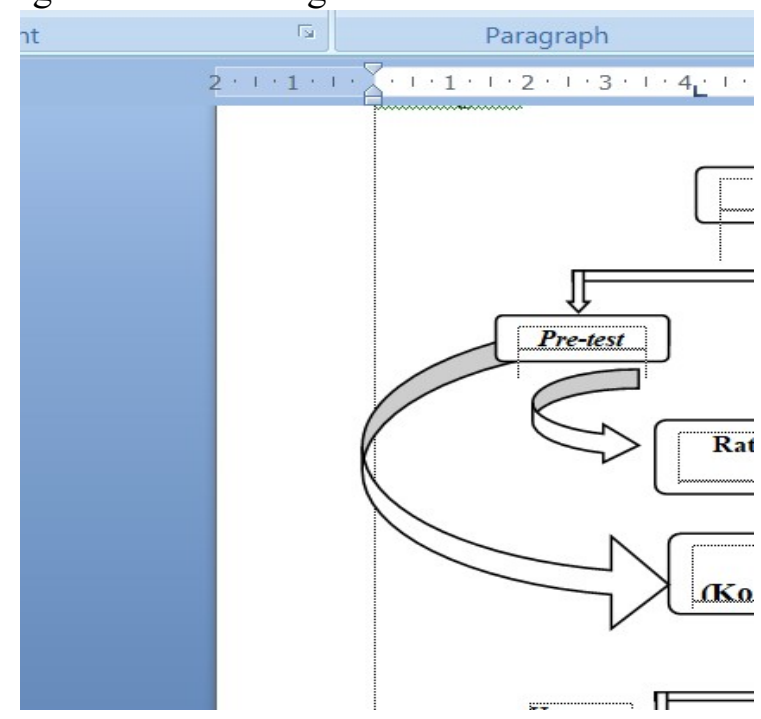




\section{HASIL PENELITIAN}

\section{Deskripsi Pelaksanaan Penelitian}

Kegiatan penelitian ini telah dilaksanakan pada tanggal 24 Juli -24 Agustus 2017 pada siswa kelas VIIIdi SMP N 1 Palibelo.Kegiatan pengajaran sesuai dengan jadwal pelajaran matematika yang telah ditetapkan oleh pihak sekolah. Penelitian ini dilakukan di dua kelas yaitu kelas eksperimen dan kelas kontrol. Kelas eksperimen yaitu kelas VIII-B yang terdiri dari 25 siswa dengan jadwal pembelajaran dilakukan setiap hari selasa dan kamis sedangkan kelas kontrol yaitu kelas VIII-E terdiri dari 25 siswa dengan jadwal pembelajaran dilakukan setiap hari jum'at dan sabtu. Untuk kelas kontrol pelaksanaan pembelajaran menggunakan metode konvensional, sedangkan pada kelas eksperimen menggunakan metode Mind Mapping bersettingTeam Game Tournament (TGT).

Peneliti sebelum melaksanakan kegiatan penelitian, terlebih dahulu melakukan uji coba instrumen pada kelas IXB SMP N 1 Palibelo. Instrumen yang diuji cobakan merupakan instrumen untuk meningkatkan prestasi belajar siswa. Instrumen tes diuji cobakan bertujuan untuk mengetahui keterbacaan dan reliabilitas soal.

\section{Deskripsi Data Hasil Penelitian}

Penelitian ini termasuk penelitian eksperimen. Data penelitian terdiri dari tes awal dan tes akhir tentang materi yang telah disampaikan dengan menggunakan metode Mind Mapping BersettingTeam Game Tournament (TGT). Penelitiandilaksanakanpada tanggal 24 Juli s/d 24 Agustus 2017. Pada tanggal 26 dan 28 yaitu pada hari rabu dan jum'at dilakukan pengujian validitas soal pre-tes dan post-tes pada kelas XI-B. Setelah peneliti mendapatkan hasil bahwa soal yang diuji cobakan ternyata valid maka peneliti memberikan perlakuan di kelas VIII-B yang merupakan kelas eksperimen, dan mulai dilaksanakan pada hari selasa tanggal 01 Agustus yang merupakan jam ke 4-6 dan rabu 02 Agustus jam ke 6-7 dan, pemberian perlakuan untuk kelas VIII-E yang merupakan kelas kontrol pada hari jum'at 04
Agustus jam ke 1-2 dan sabtu 05 Agustus jam ke 1-3.

Variabel penelitian yang ada dalam penelitian ini ada variabel bebas dan variabel terikat. Variabel bebas $(\mathrm{X})$, yaitu pengaruh pendekatan metode mind mapping bersetting pembelajaran kooperatif tipe TGT untuk meningkatkan prestasi belajar siswa pada materi aljabar, dan Variabel terikat (Y), yaitu model pembelajaran mind mapping bersetting pembelajaran kooperatif tipe TGT pada siswa kelas VIII. Data hasil belajar siswa diperoleh dengan tes berbentuk uraian.

Peneliti memperoleh data dari hasilpre-test dan post-test yang dilakukan pada kelas eksperimen dan kelas kontrol. Pre-test dilaksanakan pada hari selasa tanggal 01 Juli pada kelas eksperimen, dan hari jum'at 04 Agustus pada kelas kontrol. Pre-testmerupakan pemberian tes yang diberikan kepada siswa sebelum perlakuan, sedangkan post-test dilakukan setelah siswa mendapatkan perlakuan.Post-tespada kelas eksperimen dilaksanakanpada hari selasa 15 Agustus dan jum'at 18 Agustus pada kelas kontrol Kedua tes ini berfungsi untuk mengukur sampai mana pengaruh program pembelajaran.

Deskripsi data adalah data yang diperoleh dari pre-test dan post-test untuk mendukung pembahasan hasil penelitian, data tersebut yang akan menentukan peningkatan prestasi belajar siswa pada kelas kontrol dan kelas eksperimen. Data hasil tes untuk meningkatan prestasi belajar siswa yang akan dideskripsikan pada data pre-test dan data post-test. Data pre-test diberikan untuk mengetahui kemampuan awal siswa yang diberikan pada kelas eksperimen dan kelas kontrol sebelum perlakuan, sedangkan data post-test bertujuan untuk mengetahui peningkatan prestasi belajar siswa, yang diberikan setelah perlakuanpada kelas eksperimen dan kelas kontrol. Deskripsi data hasil pre-test dan post-test untuk prestasi belajar siswa, dapat dilihat pada Tabel 4.1 sebagai berikut:

Tabel 4.1 Deskriptsi Data Hasil Pre-test dan Post-test prestasi belajar siswa 


\begin{tabular}{|c|c|c|c|c|}
\hline \multirow{2}{*}{ Deskripsi } & \multicolumn{2}{|c|}{ Kelas Eksperimen } & \multicolumn{2}{c|}{ Kelas Kontrol } \\
\cline { 2 - 5 } & Pre-test & Post-test & Pre-test & Post-test \\
\hline Jumlah siswa & 25 & 25 & 25 & 25 \\
\hline Rata-rata & 46,4 & 50,5 & 26,8 & 70,6 \\
\hline Nilai maksimal ideal & 100 & 100 & 100 & 100 \\
\hline Nilai minimal ideal & 10 & 10 & 10 & 10 \\
\hline Nilai maksimal & 30 & 95 & 40 & 85 \\
\hline Nilai minimal & 30 & 60 & 15 & 50 \\
\hline Simpangan baku & 9,300 & 7,644 & 4,282 & 7,188 \\
\hline Varian & 46,500 & 56,917 & 43,500 & 86,083 \\
\hline Ketuntasan & $0 \%$ & $88 \%$ & $0 \%$ & $68 \%$ \\
\hline Peningkatan ketuntasan & \multicolumn{2}{|c|}{$88 \%$} & \multicolumn{2}{c|}{$68 \%$} \\
\hline
\end{tabular}

Berdasarkan hasil deskripsi data pada Tabel 4.1 di atas menunjukan bahwa nilai rata-rata pre-test pada kelas kontrol adalah 26,8 dan nilai rata-rata pada kelas eksperimen adalah 46,4. Sehingga dapat dikatakan bahwa pada kedua kelas belum ada siswa yang mencapai kriteria ketuntasan minimal yang ditetapkan yaitu $\geq 70$. Pada post-test prestasi belajar siswa kelas eksperimen nilai rata-rata yaitu 50,5dan pada kelas kontrol nilai ratarata post-test adalah 70,6.Untuk skor maksimal siswa pada kelas kontrol mencapai 85 dan skor maksimal pada kelas eksperimen mencapai 95.

Peningkatan prestasi belajar siswa dapat diamati pula melalui presentase ketuntasan kelas eksperimen dan kelas kontrol sebelum perlakuan yaitu sama-sama $0 \%$ artinya kedua kelas belum memenuhi kriteria tuntas, sedangkan setelah perlakuan masing-masing kelas mencapai $68 \%$ dan $88 \%$ artinya kedua kelas mengalami peningkatan dalam hal ketuntasan belajar.

\section{Hasil Analisis Data}

\section{a. Hasil Uji Normalitas}

Uji normalitas dilakukan untuk mengetahui apakah data berdistribusi normal atau tidak. Uji normalitas dilakukan dengan bantuan software SPSS 16 of windows dan Microsoft officel excel. Hasil uji normalitas dapat dilihat pada Tabel 4.2

Tabel 4.2 Hasil Uji Normalitas

\begin{tabular}{|c|c|c|c|c|}
\hline Kelas & $\begin{array}{l}\text { Hasil uji } \\
\text { Pre-test }\end{array}$ & $\begin{array}{c}\text { coba signifikan } \\
\text { Post-test }\end{array}$ & $\begin{array}{l}\text { Sig } \\
(\alpha)\end{array}$ & Keterangan \\
\hline $\begin{array}{l}\text { Eksperimen } \\
(\mathrm{n}=25)\end{array}$ & 0,274 & 0,350 & \multirow{2}{*}{0,05} & Normal \\
\hline $\begin{array}{l}\text { Kontrol } \\
(\mathrm{n}=25)\end{array}$ & 0,062 & 0,133 & & Normal \\
\hline
\end{tabular}

Berdasarkan Tabel 4.2 di atas, menunjukan bahwa uji normalitas data pada kelas eksperimen dan kontrol dari prestasi belajar siswa baik pada data pre-test dan posttest menunjukan berdistribusi normal. Signifikanyang diperoleh $(\mathrm{p})>$ sigtifikan ketetapan $(\alpha)$. Pada pre-test kelas eksperimen dan kelas kontrol yaitu $0,274>0,05$ dan 0,062 $>0,05$. Sedangkan pada post-test berturutturut $0,395>0,05$ dan $0,133>0,05$. Hasil uji normalitas Selengkapnya dapat dilihat pada Lampiran 35 halaman 164

\section{b. Hasil Uji Homogenitas}

Uji homogenitas dilakukan untuk menguji kesamaan varian pada sampel yang digunakan. Uji homogenitas dilakukan dengan bantuan software SPSS 16 of windows dan Microsoft officel excel. Hasil analisis homogenitas dapat dilihat pada Tabel 4.3

Tabel 4.3 Hasil Uji Homogenitas

\begin{tabular}{|c|c|c|c|c|c|}
\hline \multirow{2}{*}{ Kelas } & \multicolumn{2}{|c|}{ Hasil perhitungan } & \multirow{2}{*}{$\begin{array}{c}\text { Sig } \\
(\boldsymbol{\alpha})\end{array}$} & \\
\cline { 2 - 5 } & Singnifikan (p) & $\mathbf{d f 1}$ & $\mathbf{d f 2}$ & & \\
\hline Prer-test & 0,246 & 1 & 48 & 0,05 & Homogen \\
\hline Post-test & 0,396 & 1 & 48 & & Homogen \\
\hline
\end{tabular}

Berdasarkan Tabel 4.3 dengan tingkat signifikan $0,246>0,05$ dan $0,396>0,05$ berturut-turut pada pre-test dan post-test. Hal ini menunjukan varian pada variabel adalah homogen. Selengkapnya uji homogen dapat dilihat pada Lampiran 33 halaman 161.

\section{c. Uji Keefektifan Model Pembelajaran (One Sampel t-test)}

Uji keefektifan dilakukan untuk mengetahui pengaruh atau tidaknya pendekatan mind mapping bersetting (TGT) untuk meningkatkan prestasi belajar siswa. Uji keefektifan menggunakan uji one sampel t-test bantuan software SPSS 16 of windows dengan taraf signifikan $=0,05$ dengan derajat kebebasan masing-masing adalah $25-1=24$ dan $25-1=24$. Hasil uji keefektifan dapat dilihat pada Tabel 4.5 sebagai berikut:

Tabel 4.5 Hasil Uji Pengaruh Model dan Metode Pembelajaran.

\begin{tabular}{|c|c|c|c|c|c|c|}
\hline Kelas & Variabel & $t_{\text {hitung }}$ & Value & Df & $\begin{array}{c}\text { Sig } \\
\text { (2-tailed) }\end{array}$ & Keterangan \\
\hline Eksperimen & \multirow{2}{*}{$\begin{array}{l}\text { Prestasi } \\
\text { Belajar }\end{array}$} & 9.544 & 70 & 24 & 0,749 & Pengaruh \\
\hline Kontrol & & 0,323 & 70 & 24 & 0,000 & Tidak Pengaruh \\
\hline
\end{tabular}

Berdasarkan Tabel 4.5 di atas, dapat diketahui bahwa pada kelas eksperimen yang menggunakan metode mind mapping bersetting (TGT) untuk meningkatkan 
prestasi belajar siswa, dengan test-value 70 diperoleh $\mathrm{t}$ hitung $=$ 9.544dengan hasil signifikan $0,000<0,05$, maka H0 ditolak. Hal ini dapat disimpulkan bahwa metode mind mapping bersetting (TGT) berpengaruh untuk meningkatkan prestasi belajar siswa.

Pada kelas kontrol pembelajaran dengan metode ceramah dengan test-value 70 diperoleh $t$-hitung $=0,323$ dengan hasil signifikan $0,000>0,05$, maka $\mathrm{H} 0$ diterima. Hal ini dapat disimpulkan bahwa metode ceramah kurang efektif atau tidak berpengaruh dalam metode mind mapping bersetting (TGT) untuk meningkatkan prestasi belajar siswa.

\section{PEMBAHASAN}

Penelitian ini dilaksanakan dengan tujuan untuk mengetahui pengaruh pendekatan mind mapping bersetting(TGT) terhadap prestasi belajar siswa pada materi aljabar kelas VIII-B di SMPN 1 Palibelo. Dalam penelitian ini banyak sampel yang diambil ada 50 responden yaitu 25 untuk kelas eksperimen dan 25 untuk kelas kontrol.

Penelitian ini termasuk penelitian eksperimen karena penelitian ini bertujuan untuk mengetahui sebab akibat serta berapa besar pengaruh sebab akibat tersebut dengan cara memberikan beberapa perlakuan (Treatment) tertentu pada kelas eksperimen. Prosedur yang peneliti lakukan dalam penelitian ini adalah memberikan pengajaran dengan menggunakan pendekatan mind mapping bersetting(TGT)untuk meningkatkan prestasi belajar siswa.

Salah satu dasar pemikiran untuk melakukan penelitian dengan menerapkan suatu model dan metode pembelajaran yang berbeda dari yang sudah diterapkan di SMP N 1 Palibelo adalah masih rendahnya nilai rata-rata dan prestasi belajar siswa dalam pembelajaran matematika. Hal itu menjadi inovasi guru untuk menerapkan model dan metode pembelajaran yang baru dan berbeda dari sebelumnya. Berbagai model dan metode pembelajaran perlu untuk dilakukan percobaan untuk meningkatkan mutu pendidikan dan kemampuan siswa.

Jurnal Ilmiah Mandala Education
Sebelum melakukan eksperimen dengan menggunakan pendekatan mind mapping bersetting(TGT)untuk meningkatkan prestasi belajar siswa dan juga menggunakan metode ceramah, peneliti melakukan uji validitas instrumen yang divalidasi oleh dua orang dosen ahli. Pada penelitian ini, diterapkan pada pendekatan mind mapping bersetting(TGT)untuk meningkatkan prestasi belajar siswa pada kelas eksperimen dan metode ceramah pada kelas kontrol. Untuk mengetahui pengaruh pendekatan mind mapping bersetting(TGT)untuk meningkatkan prestasi belajar siswa mengacu pada kriteria ketuntasan minimal (KKM) yaitu 70 dan setelah dilakukan uji one sample ttest dengan acuan nilai KKM dan nilai signifikannya $<0,05$.

Berdasarkan hasil data sebelum perlakuan, kedua kelas belum ada yang mencapai KKM yang ditetapkan yaitu 70 . Dapat pula, diperoleh informasi bahwa kedua kelas sampel berdistribusi normal dan homogen serta mempunyai nilai ratarata kemampuan awal yang sama. Dengan demikian peneliti akan melanjutkan penelitian dengan membandingkan hasil kelas eksperimen dengan menggunakan pendekatan mind mapping bersetting(TGT)untuk meningkatkan prestasi belajar siswa dan kelas kontrol dengan metode ceramah, keduanya ditinjau untuk meningkatkan prestasi belajar siswa.

Setelah diberikan perlakuan, dengan menggunakan uji one sample t-test untuk hipotesis pengaruh model dan metode pembelajaran untuk meningkatkan prestasi belajar siswa pada kelas eksperimen diperoleh nilai $t$-hitung adalah 9.544dan signifikannya adalah $0,749<0,05$ sehingga Ho ditolak atau pendekatan mind mapping bersetting(TGT) tidak berpengaruh untuk meningkatkan prestasi belajar siswa Sedangkan Pada kelas kontrol pembelajaran dengan metode ceramah dengan test-value 70 diperoleh t-hitung $=$ 1,447 dengan hasil signifikan $0,161>0,05$, maka $\mathrm{H}_{0}$ diterima. Hal ini dapat disimpulkan bahwa metode ceramah tidak 
berpengaruh untuk meningkatkan prestasi belajar siswa

Dengan demikian dalam penelitian ini menggunakan model dan metode pembelajaran dengan pendekatanmind mapping bersetting(TGT)berpengaruh terhadap prestasi belajar siswa pada materi aljabar kelas VIII SMP N 1 Palibelo. Hasil penelitian tersebut didukung oleh penyataan (Slavin 2009: 84) bahwa pembelajaran kooperatif mudah diterapkan melibatkan aktivitas seluruh siswa menfasilitasi siswa berinteraksi secara aktif dan positif dalam kelompok, dimana siswa dapat saling menukar dan mngeluarkan ide-ide yang muncul dalam suasana yang menyenangkan. Dengan demikian hasil pembelajaran dapat dimaksimalkan dalam rangka mengekspor kemampuan siswa dalam menyelesaikan permasalahan yang diberikan dan siswa lebih paham sehingga siswa dapat meningkatkan prestasi belajar.

Adapun kesulitan pada saat penelitian yang dialami peneliti yaitu (1) banyak yang ribut dalam kelas sehingga memicu teman yang lain tidak bisa konsen dengan yang dijelaskan di depan sesekali peneliti melontarkan teguran pada siswa yang membuat keributan di dalam kelas, (2) kurang pahamnya siswa dalam materi yang dipelajari sehingga peneliti menjelaskan secara jelas dan memberikan peluang pada siswa untuk bertanya dari materi yang belum mereka pahami dan membuat siswa lebih aktif dari biasanya, (3) siswa terlihat jenuh pada saat pembelajaran sehingga peneliti melakukan selingan dan melanjutkan kembali pembelajaran.

Pengunaan metode dan model pembelajaran yang disettingkan maka dari pendapat Swadarma (2013: 68) \& Slavin (2009: 84) dipadukan maka peneliti menyimpulkan bahwa dengan menggunakan mind mapping sebagai metode untuk penyelesaian soal yang diberikan dengan bersetting model pembelajaran tipe TGT dalam pembentukan kelompok sesuai dengan sintaks pembelajaran tipe TGT. Settingan ini sangat bermanfaat dan membuat siswa Jurnal Ilmiah Mandala Education lebih aktif dari biasanya dan untuk menyesaikan tugas yang diberikan tiap kelompok dapat mengerjakan bersamasama dengan baik, dan dengan menggunakan metode ini akan meningkatkan prestasi belajar siswa dalam pelajaran matematika.

\section{KESIMPULAN}

Berdasarkan hasil penelitian dan pembahasan, pengaruh pendekatan Mind Mapping bersetting Team Game Tournament (TGT) terhadap prestasi belajar siswa kelas VIII SMPN 1 Palibelodapat disimpulkan bahwa pengunaan pendekatan Mind Mapping bersetting Team Game Tournament (TGT)berpengaruh terhadap prestasi belajar siswa kelas VIII SMPN 1 Palibelo dan, metode pembelajaran ceramah kurangberpengaruh untuk meningkatkan prestasi belajar siswa materi aljabar kelas VIII SMPN 1 Palibelo.

\section{SARAN}

Berdasarkan kesimpulan di atas peneliti mengajukan beberapa saran sebagai berikut:

1. Disarankan kepada guru matematika untuk menggunakan model dan metode berupa pendekatan Mind Mapping bersetting Team Game Tournament (TGT) lebih khususnya untuk meningkat prestasi belajar siswa terutama pada materialjabar.

2. Disarankan kepada peneliti yang berikutnya agar mengantisipasi suatu hal yang dapat mempengaruhi hasil penelitian, seperti kurang maksimalnya dalam menerapan model pembelajaran yang digunakan.

3. Disarankan pada peneliti untuk jelih dalam memilih metode atau model pembelajaran yang tepat dan sesuai dengan kondisi siswa.

4. Disarankan kepada peneliti selanjutnya agar dapat menjalin komunikasi dan evaluasi yang baik dengan pihak sekolah sehingga hal-hal yang menjadi kekurangan dapat segera diatasi dengan solusi terbaik.

\section{DAFTAR PUSTAKA}

Agus, Tyaningrum Nina. 2016.Program Studi Pendidikan Matematika Fakultas Keguruan dan Ilmu Pendidikan Universitas Riau Kepulauan Batam 
(Pengaruh Penggunaan Media Pembelajaran Mind Mapping Terhadap Prestasi Belajar Matematika Siswa Kelas VII SMP Tunas Baru Jin-Seung Batam). PYTHAGORAS, 5(1): 32-37 April $2016 \quad$ ISSN 2085-9996.di Terbitkan. [Online] Tersedia: http://www.e-jurnal.com [April 2016].

Arifin Ahmad, Muhammad. 2009. Kinerja Guru Pembimbing Sekolah Menengah Umum. Disertai doktor. UNJ. Jakarta.

Arikunto. 2009.Prosedur Penelitian Suatu Pendekatan Praktek. Jakarta: Rineka Cipta.

Baru Algensido.

Basuki. T. 2010. Pembelajaran Matematika disertai Penyusunan Peta Konsep. Tesis. Bandung. PPs upi Bandung .

Buzan, Tony. 2010.Buku Pintar Mind Mapping untuk Anak. Jakarta: Gramedia.

Cunayah,Cucun dkk. 2008.Pelajaran Matematika Untuk SMP/MTS Kelas VIII, (Bandung: CV.Yrama Widya)

Darmadi, 2011. "Metode Penelitian Pendidikan dan Sosial". Bandung: Alfabeta.

Djaali dan Pudji Muliyono,2015.Pengukuran Dalam Bidang Pelajaran. Jakarta: Grasindo.

Djiwandono, Wuryani, 2009. Psikologi Pendidikan. Jakarta: PT Grasindo.

Dzamarah, 2015. "Keterampilan Belajardan pembelajaran”. Jakarta:PT.RinekaCipta.

Dzamarah, Syaiful Bahri \& Anwar Zain, 2012. Strategi Belajar Mengajar. Jakarta:

Dzamarah, Syaiful Bahri, 2012. Strategi Belajar Mengajar. Jakarta: PT. Rineka Cipta.

Engineering Statistics Hanbook,2009. Kolmogorov- Smirnov Goodnes of theFit

Enny, Rusmawati Putu,2013.Pengaruh Model Pembelajaran Kooperatif TGT Terhadap Prestasi Belajar Matematika Ditinjau dari Motivasi Berprestasi Siswa Kelas VIII SMP Negeri 2 Semarapura. e-Journal Program Pascasarjana Universitas Pendidikan Ganesha Program Studi Teknologi

Jurnal Ilmiah Mandala Education
Pembelajaran (Volume 3 Tahun 2013).

Di Terbitkan. [Online] Tersedia: http://www.e-jurnal.com[01 Januari2013].

Gozali,Imam. 2013.Aplikasi Analisis MultivariateDengan Program SPSS, Cetakan ke-4, Badan Penerbit Universitas Diponegoro Semarang.

Gregory, Robert J. 2016.Psyhological Testing: History, Principles And Aplication.

Hudojo, H, et al 2011. Peta Konsep. Jakarta: Makalah disajikan dalam Forum Diskusi Pusat Perbukuan Depdiknas.

Indyati. 2014."Penerapan Metode Pembelajaran Mind Mapping Untuk Meningkatkan Hasil Belajar": S1Thesis, Studi Pendidikan Matematika Sekolah Tinggi Keguruan Dan Ilmu Pendidikan (STKIP) Taman Siswa Bima. [Tidak Diterbitkan]. Jakarta: Erlangga

Kementrian Pendidikan dan Kebudayaan Republik Indonesia. 2014.Matematika Untuk SMP/MTS Kelas VIII Semester I, (Jakarta: Pusat Kurikulum dan Perbukuan, Balidbang, Kemdikbud). Cet. Ke-1, 2014.

Kumano, Y. 2014.Authentic Assessment and Portfolio Assessment-Its Theory and Practice. Japan: Shizuoka University.

Lie, Annita. 2007.Pembelajaran Kooperatif. Jakarta: Grasindo

Muhibbin. 2013.PsikologiBelajar.Jakarta:PTRajaGr afindo Persada.

Muhmuddin. 2013. "Pembelajaran Berbasis Peta Pikiran". http://muhmuddin.wordpres.com

Nawawi. 2010. "Faktor-faktor yang Mempengaruhi Prestasi Belajar". Jakarta: Rineka Cipta.

Nirmala, Dyah. 2015. Statistik Deskriptif \& Regresu Linear Berganda Dengan SPSS. Semarang: Semarang University Press

Nurhidayah. 2013."Penerapan Metode Pembelajaran Kooperatif Tipe TGT (Team Game Tournament) pada Materi Operasi Hitung Bilangan Bulat Untuk Meningkatkan Aktivitas Dan Prestasi 
Belajar Siswa": S1 Thesis, Studi Pendidikan Matematika Sekolah Tinggi Keguruan Dan Ilmu Pendidikan (STKIP) Taman Siswa Bima. [Tidak Diterbitkan].

PT. Rineka Cipta Cet. III.

Purwanto, M. N. 2011. Psikologi Pendidikan. Remaja Rosda Karya. Bandung.

Rianto. 2013.Metode Penelitian Sosial dan Hukum. Jakarta: Granit.

Sagala. 2012.Teori Pembelajaran. Jakarta: Grasindo

Slameto. 2013.Belajar dan factor-Faktor Yang Mempengaruhinya. Jakarta: Rineka Cipta

Slavin, R.E. 2009.Psikologi Pendidikan. Jakarta: Rineka Cipta

SMPN 1 Palibelo. 2017.Data Nilai Prestasi Belajar Mata Pelajaran Matematika. Tidak diterbitkan.

Sontani, 2014. "Desain Penelitian Kuantitatif". Bandung: Karya Adhika Utama

Sudjana, Ahmadi. 2015. "Dasar-dasar Proses Belajar Mengajar”. Bandung: Sinar

Sudjana,Nana. 2004. Dasar-dasar Proses Belajar Mengajar. Bandung. Sinar Baru Algensindo.

Sudjana. 2009.Teknik Analisis Regresi dan Korelasi.Bandung: Tarsito.

Sugiyono, 2012. Metode Penelitian Pendekatan Kuantitafi, Kualitatif, dan R\&D. Bandung: Alfabeta.

Sugiyono. 2015.Statistik Untuk Penelitian. Bandung. Alfabeta.

Suharsimi. 2012. Prosedur Penelitian: suatu pendekatan praktis. Jakarta: Rineka Cipta.

Sukmadinata, 2009.Rancangan Penelitian. Bandung: Rosda.

Swardiman, Doni. 2013.Mind Mapping dalam Kurikulum Pembelajaran. Jakarta: Elex Media Komputido. test. USA:NITS Sematech

Tritonegoro. 2011. "Prestasi Belajar dan Program Pendidikan”. Jakarta: Bumi Aksara. 